\title{
4. Australian media \\ coverage of two pivotal climate change summits A comparative study between COP15 and COP21
}

\begin{abstract}
From an international perspective Australia's 'climate change wars' can be challenging to grasp (Chubb, 2014). Part of the explanation to the protracted divisions on meaningful action on climate change can be found in media coverage of the issue. This makes Australia an interesting case study from an international and journalism studies perspective.

This article compares the coverage in two major Australian newspapers of the two pivotal climate change summits in Copenhagen in 2009 and in Paris 2015. The primary research question was: in what way, if any, has the reporting of two major international climate change meetings in The Sydney Morning Herald and the Daily Telegraph changed over time?

The project used a mixed methods approach drawing on longitudinal content analysis data and interviews conducted with senior Australian journalists. The approach generated rich data allowing for a discussion using the "wicked policy problem' framework (Head \& Alford, 2013).
\end{abstract}

Keywords: Australia, climate change, climate summits, Copenhagen, Denmark, journalism, Paris, France

\author{
JOHAN LIDBERG \\ Monash University, Melbourne
}

\section{Introduction}

I went to a briefing [in Paris] with a representative from Greenpeace who praised the role of business and when that happens you know you're in a different world. Still a warming world, but very different to COP15 [Copenhagen climate summit in 2009]. (Reporter D, 2016) 
$\mathrm{T}$ HE CLIMATE change summits in Copenhagen in 2009 and Paris in 2015 were in the lead-up to the events both claimed to be make or break moments for global action on reducing human induced emissions driving severe climate change. Yet the largest meetings and negotiations on earth played out very differently as illustrated by the quote above.

The Conference of Parties (COP) is organised by the United Nations Framework Convention on Climate Change (UNFCC) in collaboration with the country hosting the conference. The COPs are held annually and every six years a major $\mathrm{COP}$ is scheduled where the goals for the following six years are set. Almost every recognised sovereign country participates in these summits. The COPs are the preeminent official forum for climate change negotiations. The first COP was held in Bonn, Germany, in 1995 where the UNFCC secretariat is based. To date 23 COPs have been held with COP24 scheduled for the end of 2018 in Katowice, Poland (UNFCC 2017).

Australia's commitment to the COP negotiations has varied greatly and has been dependent on the government of the day. The country has been through close to 20 years of disruptive 'climate change wars' (Kelly, 2017) where climate change sceptics and fossil fuel and mining lobby groups have fought it out both publicly and behind the scenes (Cohen, 2006) with environmental groups, some political parties, climate scientists and lately business forces, that want extensive action on curbing emissions.

The climate change wars are well documented and have of course been fought in media reporting as well (Chubb, 2010; Bacon, 2011; Chubb, 2014). This makes the media coverage of the COPs interesting to assess and analyse, especially those summits that are high profile attracting most world leaders. COP15 in Copenhagen in 2009 and COP21 in Paris in 2015 are two such conferences. As we shall see in the findings from the interviews below, the major COPs are world events where country leaders meet on the international stage while still playing to their domestic audiences.

This article describes the findings from a longitudinal content analysis study capturing the reporting from the COPs 15 and 21 in two major Australian media outlets addressing the core question: in what way, if any, has the reporting of two major international climate change summits in The Sydney Morning Herald (SMH) and the Daily Telegraph (DT) changed over time? To complement the content analysis an interview study was conducted where five senior climate change/environment/politics reporters were interviewed before they departed for COP 21 and again after their return.

Climate change is, of course, one of the greatest challenges humankind has faced (Hansen, 2009) and it is truly global in nature, which means that inaction is not an option for any stakeholder or country. To assist with the discussion and analysis, a part of policy studies labelled 'wicked policy problems' was 
employed (Head \& Alford 2013). Media coverage of climate change feeds into policy making, which makes it important to capture and analyse this reporting. Australian media coverage has shifted over time, reflecting the very different final outcomes of COP15 and COP21. It should be pointed out from the outset that this is an empirically data driven project and that the study does not seek to add to the wicked problems theory framework, but rather use the framework to inform the discussion of the data captured.

This article will first provide the background and context to the study, then move into a brief literature review and methodology description, followed by the data presentation and end with a discussion and a conclusion pointing to future research.

\section{Background and context}

The research conducted for this article is part of a 20 nation transnational research network that has monitored media coverage of climate change in the countries of study since 2007 . This is how the research group describes itself:

The MediaClimate project looks into global climate change coverage in twenty countries. It sets out to analyse climate change in journalism both (1) as a manifestation of the rapidly changing context wherein contemporary journalism takes place and develops and (2) as an illustration of the political reformation of the issue of climate change in the post-Copenhagen (COP15) era (MediaClimate, 2017).

The principal strength of the group is that it includes members from the OECD and emerging and developing countries from around the globe, which means that the three books the group has produced provide a truly global snapshot of the state of climate change reporting (Eide et al, 2010; Eide et al, 2012; Kunelius et al, 2017).

In each country, two major newspapers were selected on the basis of elite and popular style. In Australia, The Sydney Morning Herald and the Daily Telegraph were chosen based on these criteria and also because they represent different approaches in reporting climate change. This is discussed further below. The research aims of the content analysis were both quantitative and qualitative. The first goal was to map how much coverage of climate change the COPs generated. Here all climate change stories were included, both the ones specifically relating to the COPs and general climate change stories. The second aim was to capture what voices/sources the journalists used in their stories. In Boykoff's words, 'who speaks for the climate?' (2011).

To make sure that the data captured could be compared over time, building a longitudinally valid time series, the same coding instrument was used to code 
both COPs. The data set is large. In total, the Australian part of the study identified and coded 247 articles during the COP15 event and 273 for the COP 21 summit.

\section{Previous work and framework}

There is now a large, and still growing, international body of work investigating media coverage of climate change (see Boykoff \& Boykoff, 2004; Oreskes and Conway, 2010; Bacon, 2011; Boykoff, 2011; Chubb \& Bacon, 2012; Lester \& Hutchins, 2013; Chubb, 2014; Hackett et al., 2017).

Boykoff identified and labelled 'balance as bias' (2004) showing that many journalists, while striving for the professional goal of objectivity, framed human induced climate change as still being a matter of scientific discourse and often interviewed one scientist arguing for the science and one opposed portraying it as a 50/50 argument when in fact for more than a decade there had been a 97 percent consensus among climate scientists that human induced climate change was indeed happening (Oreskes \& Conway, 2010).

The case studies of environmental conflict in the media in Lester and Hutchins (2013) situated the conflict and communication of climate change in the local and global perspectives with particular emphasis on the role played by new networked media and activism. Chubb (2014) documented and outlined in devastating detail the hopes for meaningful action on climate change in Australia following the 2007 federal election and how fossil fuel lobby group interventions derailed the policy process leading to the eventual partial collapse of Australian climate change policy in 2014.

Following Boykoff's and Oreskes' pioneering work, studies across the globe (see for instance Eide et al, 2010; 2012, Kunelius, et al 2017) found that the main issue was not the quantity of stories that reported climate change, the issue was how climate change was being reported, of which the balance as bias example above is a potent example. In the case of Australia (which also applies globally) Hackett et al. (2017) identified a greater need for journalism to report on the adaptation to the climate crisis and act as a bridge builder between the different factions in the climate change wars mentioned in the introduction. As we shall see in the findings and discussion part of this article, although the reporting of climate change has changed over time in Australia, the issue of how reportage is produced is still a prominent issue.

The framework in which the findings in this article are discussed sits in policy studies in a particular subsection labelled in the 1970s as 'wicked policy problems'. The concept of wicked policy problems provides an interesting prism by which to regard media coverage of climate change, as reporting influences public opinion and climate change policy is dependent on the public understanding the urgency and extent of the change needed to be able to design effective policies that will be accepted and embraced by the public. 
Scholars define a wicked policy problem as one where there is no single or clear definition of the limits of the problem and hence no ultimate single solution to it (Compston, 2009). Climate change is due to its complexity a stand out example of such a problem. Asayama et al elaborate:

Climate change is a conflict between the market and the environment, between rich and poor countries and between present and future generations, just to mention some of the obvious dimensions. Because such fundamental stakes are at play, and due to the different ideas, values and worldviews involved in the debate (Hulme, 2009), it is immensely difficult to reach a consensus on specific policy responses to climate change (2017, p. 172).

The wicked policy problem framework will be used in this article to assess to what extent the media coverage analysed contributes to defusing the wicked policy problem or if the media contributes to making the climate change policy issues even harder to solve.

One important limitation in this study is that the findings cannot be generalised across the full media spectrum in Australia as only two outlets were analysed. Having said that, the two publications are far apart on the climate change reporting continuum in Australia and as such are representative of how much climate change reporting has been conducted in Australia during the last ten years in mainstream media. The findings are not applicable to niche media focusing on, for instance, the economy of climate change or environmental reporting in general. It should also be noted that the DT is owned by News Corp Australia who in the last decade focused its reporting heavily on climate change scepticism. The company controls 60 percent of the Australian newspaper market. The SMH is owned by the second largest, but much smaller media owner, Fairfax Media Limited. Studies show that News Corp's publications internationally also dedicate a lot of editorial space to climate change scepticism (McKnight, 2012). With this in mind, the findings in this study are highly relevant to countries with a high proportion of News Corp owned media. A possible further limitation is that the audiences of the two publications are quite different and it should be acknowledged that this fact most likely had some impact when resourcing and publication decisions regarding COP15 and COP21 were made. However, it could be argued that global meetings such as COPs 15 and 21 should have high relevance to all audiences and that this topic therefore is a valid one when comparing coverage by elite and popular media.

\section{A mixed methods approach}

As Neuman points out, a mixed methods approach is often the most potent research design to address research questions involving complex interactions 
between human beings (2013). In this case the combination of quantitative and qualitative data further strengthened the research design (Denzin, 2013).

The core methodology used was a longitudinal content analysis covering both the COP15 Copenhagen and COP21 Paris climate summits. The choice of The Sydney Morning Herald and the Daily Telegraph as a representation of Australian media coverage of climate change, was partly determined by the need to pick two media organisations that were still publishing news in hard copy. In a number of the 20 countries in the full study, the dominant and most prominent journalism is still published in hard copy and to make the study internationally comparative, such outlets had to be chosen across all countries. As we shall see, in Australia both hard copy and online stories were captured and coded.

Another justification for choosing these two Australian newspapers was that they take vastly different approaches to reporting climate change. The DT being a News Corp Australia publication has campaigned actively for a number of years both against the validity of climate change science and action on climate change. The SMH had been far more neutral in its coverage and at times campaigned for the need for climate change action (Chubb, 2012; McKnight, 2012; Chubb, 2014). Even though the circulations of both publications have declined, they still have considerable reach and influence over public opinion, especially at the time of the two climate summits analysed in this study. At the time of COP15 the DT had a weekday circulation of 349,635 copies, the SMH had 209,011. At COP21 in 2015 the figures had declined to 241,371 for the DT and 112,299 for the SMH. Some of the drop in hard copy circulation was offset by an increase in digital substructions. In December 2015, the digital subscriptions for the SMH were reported to be 138,165. News Corp Australia does not release digital substructions figures for the DT (Ward, 2016).

The key words used to identify and capture the articles were for COP15: 'Copenhagen' or 'climate' and 'global warming'. The dates coded were 1/12/2009 to $22 / 12 / 2009$, so five days before the summit started on $7 / 12 / 2009$ and four days after it had finished 18/12/2009.

The same time frame for coding was used for COP21. Coding started on $25 / 11 / 2015$ and finished $16 / 12 / 2015$. The summit ran between $30 / 11 / 2015$ and $12 / 12 / 2015$. The key words used identifying stories were: 'Paris' or 'climate' and 'global warming'. In both cases the primary data base used was Factiva with ProQuest used as secondary database to cross check articles and increase the validity of the sample. The coder for both COP15 and COP21 also read each hard copy of the newspapers to make sure no articles were missed. As the time period for the two studies were the same, the publications are the same and the COP15 and 21 meetings carried similar expectations and weight in terms of international participation, the results are comparable. It should also be noted that the full sample population of articles in the SMH and DT were coded during 
both summits, which limits statistical margins of error in the data.

For the COP21 meeting the content analysis was complemented by semistructured interviews with senior Australian reporters in the lead up to and after COP21. The aims of the interview study were to capture how the reporters experienced the summit compared to their expectations, the main sources they used, in what way, if any, COP21 differed from COP15 and how the different stakeholders contributed to the meeting. For confidentiality reasons, see below, it cannot be disclosed which publications the journalists reported for, but they have worked for a variety of Australian media outlets that do connect with the publications coded in this study. This means their replies are relevant to the main research question in this project.

In total five reporters were recruited for the study and interviewed. Three of the journalists had covered the COP15 summit as well and the interview study was designed to map the reporter's experiences and perceptions comparing COP15 and COP21. One of the journalists attended his first climate conference in 1997 (COP3) in the lead up to the Kyoto protocol. The interviews complemented the findings in the content analysis, which were more quantitative in nature. Four of the reporters were senior journalists and one was a mid-career reporter. It was decided to anonymise the interviewees so they could talk completely openly about all aspects of their work and experiences at COP21, including their assessment of the role of politicians and the overall performance of the Australian delegation.

A lot of effort was spent on trying to recruit a reporter from a News Corp Australia publication. One News Corp Australia reporter initially agreed to be interviewed, but when the time for the first interview came did not respond in spite of several prompts from the author.

\section{Results and findings}

It was decided that the best way to provide overview of the data from the two summits was by using comparative tables. Although online publication of articles was common in 2009, the print stories and online stories were the same story. The editorial policy of 'digital first', that is publish the story online before it went to print, had not yet been bedded in. In 2015, digital first was a firmly

\begin{tabular}{|l|c|c|c|c|}
\hline \multicolumn{3}{|c|}{ Table 1: Number of articles published and coded } \\
\hline & $\begin{array}{c}\text { COP15 Copenhagen, 2009 } \\
\text { n=247 (print and online) }\end{array}$ & \multicolumn{2}{c|}{$\begin{array}{c}\text { COP21, Paris 2015 } \\
\text { n=273 (print and online) }\end{array}$} \\
\hline Point of measure & SMH & DT & SMH & DT \\
\hline No of print articles & $168(68 \%)^{*}$ & $79(32 \%)$ & $61(22 \%)$ & $52(19 \%)$ \\
\hline No of online articles & $\begin{array}{c}\text { Print and } \\
\text { online same }\end{array}$ & $\begin{array}{c}\text { Print and } \\
\text { online same }\end{array}$ & $157(58 \%)$ & $3(1 \%)$ \\
\hline
\end{tabular}

Note: * Percentage of total number of articles published by both newspapers 
established policy at both publications, illustrated by the number of online only stories published by the SMH.

What stands out in Table 1 is the low priority covering COP 15 had in the DT, compared to the SMH from a quantitative perspective. DT published less than half the number of articles compared to the SMH. The downward trend for DT continued in the COP21 data set. During the Paris summit, the DT produced only $1 / 5$ of the number articles that the SMH published.

What is also striking about the COP2 1 data is that the DT only published three articles online covering climate change and/or COP21 during the summit. This in spite of the digital first publication editorial policy being active.

The SMH went the other way- 58 percent of the articles were published online. A further illustration of the SMH prioritising online articles was the fact that the newspaper's online news site ran a dedicated banner across the top of its news site during the full duration of the summit. Under this banner the COP21 stories were gathered for easy navigation for the reader.

In sum: from a quantitative perspective, the SMH significantly increased its coverage during COP21 compared to COP15, while the DT significantly reduced its reportage.

\begin{tabular}{|l|c|c|c|c|}
\hline \multicolumn{2}{|l|}{ Table 2: Type of story } \\
\hline & \multicolumn{2}{|c|}{$\begin{array}{c}\text { COP15 Copenhagen, 2009 } \\
\mathbf{n = 2 4 7} \text { (print and online) }\end{array}$} & \multicolumn{2}{c|}{$\begin{array}{c}\text { COP21, Paris 2015 } \\
\mathbf{n}=\mathbf{2 7 3} \text { (print and online) }\end{array}$} \\
\hline Point of measure & $\begin{array}{c}\mathrm{SMH} \\
\mathrm{n}=168\end{array}$ & $\begin{array}{c}\mathrm{DT} \\
\mathrm{n}=79\end{array}$ & $\begin{array}{c}\text { SMH } \\
\mathrm{n}=218\end{array}$ & $\begin{array}{c}\mathrm{DT} \\
\mathrm{n}=55\end{array}$ \\
\hline Type of story & & & & \\
\hline News & $95(56 \%)$ & $47(59 \%)$ & $140(64 \%)$ & $37(67 \%)$ \\
\hline Features/In-depth & $19(11 \%)$ & $0(0 \%)$ & $18(9 \%)$ & $0(0 \%)$ \\
\hline Editorial/opinion & $48(29 \%)$ & $29(36 \%)$ & $42(19 \%)$ & $13(24 \%)$ \\
\hline Other & $6(4 \%)$ & $3(5 \%)$ & $18(8 \%)$ & $5(9 \%)$ \\
\hline
\end{tabular}

The most revealing finding illustrated in Table 2 is the fact that the DT published 0 percent feature or in-depth stories analysing the negotiations during COP15 or COP21. Another interesting data point is that the number of editorials/opinion pieces in the DT shrank from 36 percent in 2009 to to 24 percent during the 2015 summit. A possible explanation to this can be found in Table 3 next page.

Table 3 reveals the biggest change of any data point comparing the two summits. The DT went from only 1 percent of the stories being produced by a news agency at COP 15 to 51 percent at COP21. This further illustrates how the DT clearly allocated less resources to cover the Paris summit compared to the 


\section{Table 3: Origin of story}

\begin{tabular}{|l|c|c|c|c|}
\hline & \multicolumn{2}{|c|}{$\begin{array}{c}\text { COP15 Copenhagen, 2009 } \\
\text { Percentage of story origin }\end{array}$} & $\begin{array}{c}\text { COP21, Paris 2015 } \\
\text { Percentage of story origin }\end{array}$ \\
\hline Point of measure & $\begin{array}{c}\text { SMH } \\
\mathrm{n}=168\end{array}$ & $\begin{array}{c}\mathrm{DT} \\
\mathrm{n}=79\end{array}$ & $\begin{array}{c}\text { SMH } \\
\mathrm{n}=218\end{array}$ & $\begin{array}{c}\mathrm{DT} \\
\mathrm{n}=55\end{array}$ \\
\hline News agency story & $3 \%$ & $1 \%$ & $17 \%$ & $51 \%$ \\
\hline Staff reporter home desk & $71 \%$ & $87 \%$ & $33 \%$ & $42 \%$ \\
\hline Reporter of COP & $14 \%$ & $0 \%$ & $33 \%$ & $0 \%$ \\
\hline Other & $12 \%$ & $12 \%$ & $17 \%$ & $7 \%$ \\
\hline Total & $100 \%$ & $100 \%$ & $100 \%$ & $100 \%$ \\
\hline
\end{tabular}

Copenhagen meeting. Another telling number is the change in staff reporter at home desk produced stories - 87 percent in 2009 compared to 42 percent in 2015.

The SMH went the other way and doubled its resources covering COP21 compared to COP15. This is most clearly illustrated by the number of stories produced by reporters at the COP - up from 14 percent in 2009 to 33 percent in 2015.

The DT had 0 percent stories produced by reporters at both COPs. This is particularly surprising at COP21 as News Corp Australia (the owner of the DT) had a reporter on the ground filing for the nationwide publication The Australian. The most interesting shift is the significant drop in voices from the national political system. This shift is probably explained by a change in favour of voices from civil society and a slight increase in voices from the business community.

\begin{tabular}{|l|c|c|}
\hline Table 4: Voices & $\begin{array}{l}\text { COP15 Copenhagen, 2009 } \\
\text { Percentage of primary/ } \\
\text { first voices quoted in SMH } \\
\text { and DT }\end{array}$ & $\begin{array}{l}\text { COP21, Paris 2015 } \\
\text { Percentage of primary/ } \\
\text { first voices quoted in SMH } \\
\text { and DT }\end{array}$ \\
\hline National political system & $55 \%$ & $30 \%$ \\
\hline Foreign political system & $4 \%$ & $21 \%$ \\
\hline $\begin{array}{l}\text { Transnational political } \\
\text { system/foreign political } \\
\text { system }\end{array}$ & $5 \%$ & $3 \%$ \\
\hline Civil society & $9 \%$ & $22 \%$ \\
\hline Business & $6 \%$ & $8 \%$ \\
\hline Science/expert & $20 \%$ & $15 \%$ \\
\hline Other & $1 \%$ & $1 \%$ \\
\hline Total & $100 \%$ & $100 \%$ \\
\hline
\end{tabular}


This is a theme that reoccurs in the interviews below. It should also be noted that the number of international voices increased significantly in 2015 compared to 2009, which also explains the drop in the number of domestic voices. This change in primary voices (Table 4 ) is also reflected by some of the interview answers below.

The content analysis was complemented by interviews with five reporters accredited to cover COP 21 for five different publications. The pre-Paris interview was conducted during October and November 2015 and focussed largely on their preparations for the summit. It was also an important opportunity to build rapport between the researcher and the interviewees. The second interview took place during January and February 2016. During transcription the replies were grouped into main themes addressing the research aims outlined above. The most important replies are presented in Table 5 to provide overview.

\section{Discussion}

The most important take away from this study is that SMH coverage has grown in resources, complexity and analysis informing its audience on climate change, while the DT has gone from actively campaigning against climate change action, to more or less ignoring it, abdicating the responsibility to constructively inform its audience about the Paris agreement. The magnitude of this development from a public interest journalism point of view should not be underestimated. The Paris Agreement on global action limiting the effects of climate change is arguably the most complicated achievement in human affairs since the writing, negotiating and passing of the Universal Declaration of Human Rights in 1948. You could argue it is an even greater achievement based on the wicked nature of the climate change policy problem. In spite of the weight and importance of this event, one of Australia's largest circulation newspapers decided to all but ignore it from a resource and analysis point of view.

One possible explanation in the drop in DT coverage could be the high number of reporter jobs that had been cut in Australian newspaper news rooms between 2009 and 2015. However, these cuts apply to the SMH as well and it decided to increase rather than decrease its coverage of COP21 compared to COP15. So, in the end it appears to be more a question of prioritising what to cover rather than a resource question only.

This is illustrated by the severe drop in DT articles covering the Paris summit. During COP15 the DT produced 79 articles, this shrank to 55 during COP21. Another vital data point illustrating the DT's low priority of covering COP21 was the extreme increase in stories sourced from international news agencies. For the Copenhagen summit only 1 percent of the stories were from newsagencies, during COP21 51 percent, more than half the stories, were from newsagencies. And a final figure showing how the editorial leadership of the DT has lost interest in 


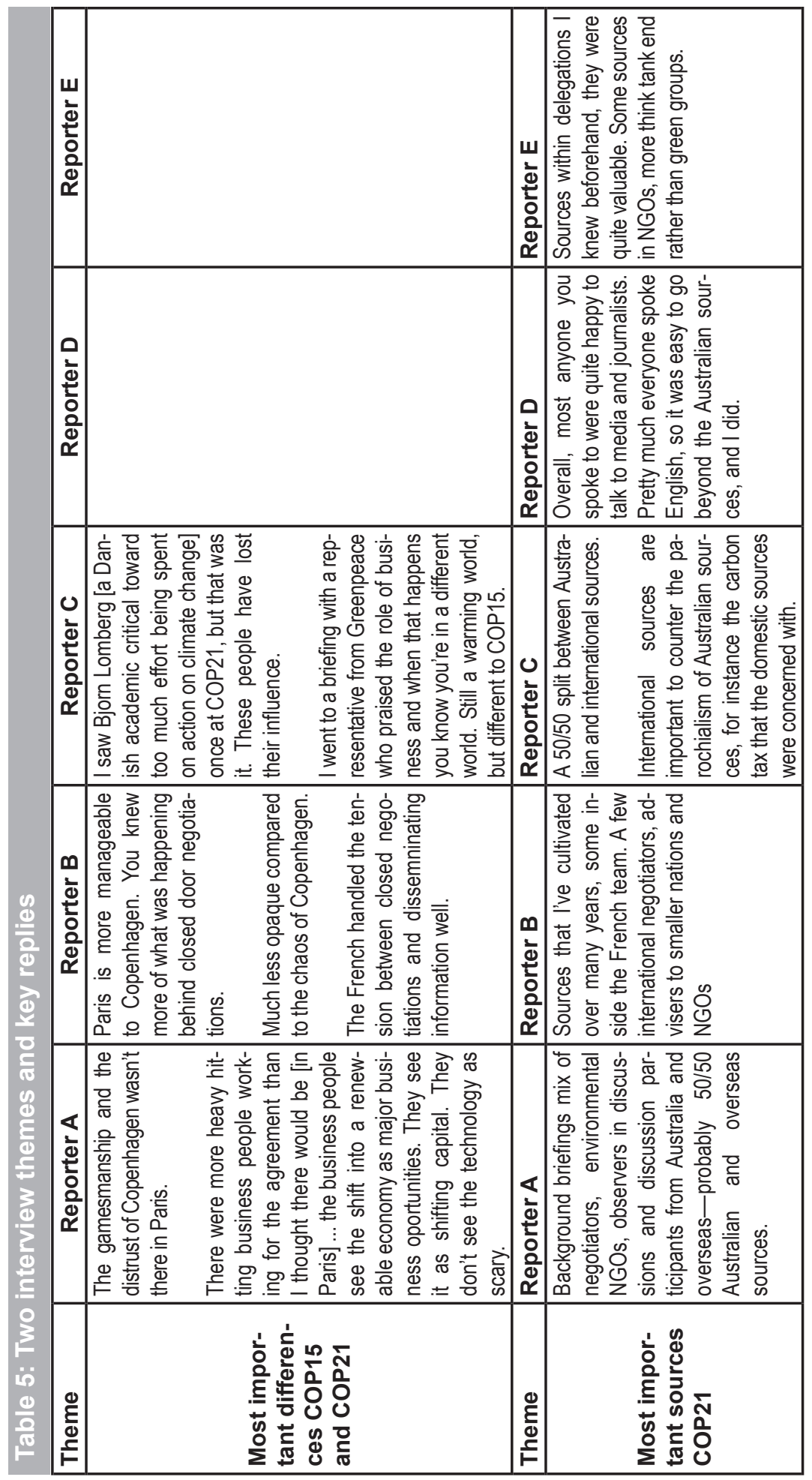




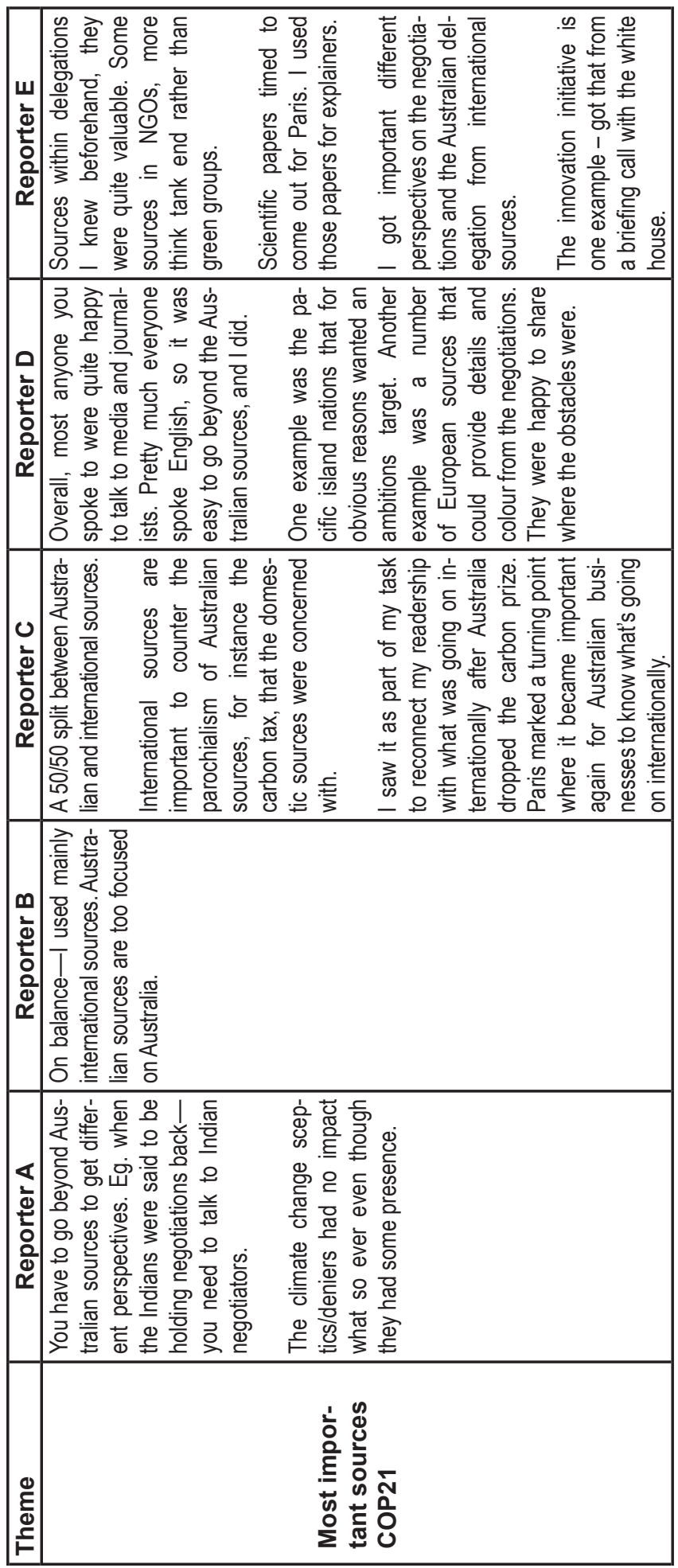


covering climate change is that the number of editorial and opinion pieces also dropped between COP15 and COP21. From 36 percent during Copenhagen to 24 percent during the Paris meeting. It should also be noted that the DT did not send a reporter to Copenhagen or Paris.

One possible explanation of the trends identified by the content analysis could be the decline in influence of climate sceptics and the fact that one of the core arguments for Australian inaction on climate change disappeared with the Paris agreement - that the rest of the world and the biggest polluters were not acting, so why should Australia? After the Paris agreement where 190 countries (all but two of the recognised sovereign nations in the world) signed up to the goal of keeping global warming to 1.5 degrees, the global inaction argument is now truly dead. This makes writing opinion pieces against action on climate change an increasingly difficult task.

The decline of the climate change sceptics lobby was strongly confirmed in the reporter interviews. However, the most important finding in the interviews was the consensus among all five interviewees that the new and growing alliances between environmental groups, NGOs and business and venture capitalists are now the most potent forces for rapid change and action on climate change. It was also interesting to note that the interviewees gave high marks to the Australian diplomats and public servants, while they were less impressed with the Australian ministers. A third important take away from the interviews was the importance the reporters allocated to a diversity of sources, with particular emphasis on finding and cultivating non-Australian sources. Perhaps they had learned from the Copenhagen coverage where the stories where dominated by domestic Australian political sources.

So, what happens if we apply the 'wicked policy' framework to the findings? In their seminal work on wicked problems, Head and Alford (2013), after a very thorough review of the literature, identify a continuum of wicked problems where type one problems represent the benign side of the continuum where the problem definitions are agreed upon by most stakeholders and where the policy solutions are relatively clear. Moving along the wickedness scale Head and Alford arrive at the following more complex problem types:

Type 2 situations are those where the definition of the problem is clear, but the solution is not - typically because the relevant cause- and-effect relationships are hard to discern - and therefore learning and discussion are required by both the governmental managers and the stakeholders they lead. In Type 3 situations, both the problem definition and the solution are unclear, and more extensive learning and discussion are required for all concerned. (2013, p. 7)

It could be argued that climate change, its problems and solutions are a combination 
of both type two and type three situations identified by Head and Alford. One possible avenue to address wicked problems is a holistic approach where dialogue between stake holders is crucial. One vital stake holder in climate change policy is the public/ citizens. The main challenge in any dialogue with the public is that there is not one individual or entity representing the public. Given this challenge the role of the media and journalism informing the citizens in a factual way becomes crucial. The more divided or confused the public is on the topic, the harder the dialogue process becomes.

Based on this analysis, this is where climate change sceptic reporting has caused most damage, peddling doubt and questioning climate science with scant or no valid ground for the questioning. This process has been eloquently explored in-depth and some of the global powerful actors spreading misinformation exposed in Oreskes' and Conway's seminal work 'Merchants of Doubt' (2010). The misinformation and at times outright lies regarding climate science has made it even harder for policy makers to deal with an already deeply complex area.

In sum: the SMH increased reporting depth and resources spent on describing and explaining climate change helped to defuse and potentially make climate change a less wicked policy problem. Compared to COP15, the DT coverage of COP21 was more neutral (bar its column and opinion pieces). This was partly explained by the fact that the majority of the articles published by the DT were produced by international news agencies. But overall, the DT coverage did little to defuse the wickedness of the climate change policy problem.

There is some ground to be cautiously optimistic that the Paris agreement was the turning point for meaningful action on climate change globally. The question is of course if it is too little too late? Opinion polling in Australia since the 2015 Paris agreement show a steady increase in support for deep cuts to greenhouse gas emissions. A 2017 Lowy Institute poll showed that 57 percent of Australians view climate change as a serious threat to Australia's vital interests in the next ten years. A further 27 percent view climate change as a vital but not critical threat leaving only 13 pecent of Australians taking the position that it is not an important threat at all. This puts climate change as the perceived third biggest threat to Australia behind international terrorism and North Korea's nuclear program (Oliver, 2017). This is an indicator that climate change policy in Australia may become a less wicked problem in the years to come. Having said that, the current conservative coalition government is still deeply divided on the policy detail of how Australia will live up to its commitments under the Paris agreement. The challenge now is to implement the agreement and monitor that countries do deliver on their promises. Holding countries and their governments to account in relation to the Paris agreement and telling these stories is an area where media and journalism will play a crucial role as an important complement to the UN based climate change accountability system. 


\section{Conclusion}

This article has described a longitudinal research project capturing media coverage of the major climate change summits in Copenhagen in 2009 and Paris in 2015. The media outlets analysed were the Sydney Morning Herald and the Daily Telegraph. The key findings were that the SMH has increased and deepened the complexity of its coverage of the issue, while the DT has gone from actively campaigning against climate change action to an increasing indifference to the issue illustrated by the severe drop in coverage during COP21 compared to COP15 both in a quantitative and qualitative sense.

The interviews conducted with five experienced climate change reporters pointed to crucial developments and major differences between the Copenhagen and Paris summits - the exponentially growing willingness among investors and the market to back and finance renewable energy and the strong alliances that have been formed between environmental groups and market forces in the time passing between COP15 and COP21.

One of the members of the MediaClimate research group mentioned in the background section above is Canada. Australia and Canada did until just before COP21 follow similar paths of 'climate change wars' and were both very reluctant participants in the global effort to curb climate change. This raises an interesting question. Is the reporting of COPs in Canadian media similar to the Australian media coverage? The data to investigate this is available, and work is currently under way to address this question.

Australia's shared path with Canada on climate change was well illustrated by the quote from the interview with reporter $\mathrm{C}$ below. The core questions in the forthcoming article: are Prime Ministers Turnbull's and Trudeau's different political realties in government reflected in the two countries' media coverage of climate change? And can it tell us anything about how this coverage will evolve and the possible impact it will have?

Turnbull gave his speech at the same time as the Canadian PM Trudeau. His message was that Canada is back in the climate change action camp and we're here to help everyone. Turnbull gave his speech with one eye on back home and you could feel the restraint around him. A conflict between what he wanted to say and what he could say. And so he got overshadowed. It was a quite telling moment, because they were two new leaders that had replaced awful climate laggards, but Trudeau got to be free in his speech and Turnbull was restrained. (Reporter C, 2016) 


\section{References}

Asayama, S., Lidberg, J., Cloteau, A., Comby, J. B., \& Chubb, P. (2017). Who captures the Voice of the Climate? Policy Networks and the Political Role of Media in Australia, France and Japan. In Eide, E., Kunelius, R., Tegelberg, M., \& Yagodin, D. (Eds.), Media and Global Climate Knowledge-Journalism and the IPCC. (pp. 171-193). New York, NY: Palgrave McMillan.

Bacon, W. (2011). A sceptical climate: Media coverage of climate change in Australia. part 1-Climate change policy. Sydney, NSW: Australian Centre for Independent Journalism.

Boykoff, M. (2011). Who speaks for the climate? Making sense of media reporting on climate change. New York, NY: Cambridge University Press.

Boykoff, M., \& Boykoff, J. (2004). Balance as bias: Global warming and the US prestige press. Global Environmental Change, 14: 125-136.

Chubb, P. (2012). Really, fundamentally wrong: Media coverage of the business campaign against the Australian carbon tax. In Eide, E., \& Kunelius, R. (Eds.), Media meets climate-The global challenge for journalism. (pp. 179-194). Gothenburg, Sweden: Nordicom.

Chubb, P. (2014). Power failure: The inside story of climate politics under Rudd and Gillard. Melbourne: Black Inc.

Chubb, P. \& Bacon, W. (2010). Australia: Fiery politics and extreme events. In Eide, E., Kunelius, R., \& Kumpu, V. (Eds.), Global Climate, local journalisms-A transnational study of how media make sense of climate summits (pp. 51-65). Bochum/Freiberg: Projekt Verlag.

Cohen, J. (2006). The green house mafia. Four Corners. [Television report, 55min]. Sydney, NSW: Australian Broadcasting Corporation.

Compston, H. (2009). Networks, resources, political strategy and climate policy. Environmental Politics, 18(5), 727-746.

Denzin, N., \& Lincoln, Y. (2013). Collecting and interpreting qualitative materials. Thousand Oaks: Sage Publications.

Eide, E., Kunelius, R., (Eds.) (2012). Media meets climate-The global challenge for journalism. Gothenburg, Sweden: Nordicom.

Eide, E., Kunelius, R. \& Kumpu, V. eds. (2010). Global Climate-local journalisms-a transnational study of how media make sense of climate summits. Global Journalism Research Series. Bochum/Freiburg: Projekt Verlag.

Hackett, R., Forde, S., Foxwell-Norton, K., \& Gunster, S. (2017). Journalism and climate crisis: Public engagement, media alternatives. Abingdon, UK: Routledge.

Hansen, J. (2009). The storms of my grandchildren, Bloomsbury.

Head, B., \& Alford, J. (2013). Wicked problems: Implications for public policy and management. Administration \& Society 20(10), 1-29.

Hulme, M. (2009). Why we disagree about climate change. Cambridge, UK: Cambridge University Press.

Kelly, S. (2017). The great climate charade. The Monthly. Melbourne, VIC: Schwartz Media.

Kunelius, R., Eide, E., Tegelberg, M., \& Yagodin, D. (Eds.) (2017). Media and global climate knowledge-journalism and the IPCC. New York, NY: Palgrave McMillan

Lester, L., \& Hutchins, B. (Eds.) (2013). Environmental conflict and the media. New York, NY: Peter Lang.

McKnight, D. (2012). Rupert Murdoch-An investigation of political power. Sydney, NSW: Allen and Unwin. 
MediaClimate. (2017). MEDIACLIMATE - a transnational research network. Retrieved from https://mediaclimate.net/.

Neuman L. (2013). Social research methods-Qualitative and quantitative approaches, Sydney, NSW: Allyn and Bacon.

Oliver, A. (2017). Majority of Australians say climate change a critical threat to Australia's vital interests. Lowy Institute. Retrieved from www.lowyinstitute.org/publications/ majority-australians-believe-global-warming-serious-problem.

Oreskes, N., \& Conway, E. (2010). Merchants of doubt. Bloomsbury Press.

Reporter A. (2016). COP21. Interview, 2 February.

Reporter B. (2016). COP21. Interview, 29 January.

Reporter C. (2016). COP21. Interview, 9 February.

Reporter D. (2016). COP21. Interview, 29 January.

Reporter E. (2016). COP21. Interview, 22 January.

UNFCC. (2017). United Nations Framework Convention on Climate Change. Retrieved from http://unfccc.int/2860.php.

Ward, M. (2016). The Australian's circulation now double that of rival AFR as Fairfax struggles with digital subscriptions. Mumbrella. Retrieved from mumbrella.com.au/ abcs-newspapers-march-2016-australian-afr-fairfax-news-366400.

Dr Johan Lidberg is an associate professor and deputy head of journalism of the School of Media, Film and Journalism, Monash University, Melbourne, Australia. His main research areas are freedom of information, access to information and media accountability, journalism ethics and reporting climate change and the environment.

johan.lidberg@monash.edu 